\title{
EDUCATING CHILDREN TO BE A DISCIPLINE PERSON
}

\author{
Daviq Chairilsyah \\ daviqch@yahoo.com \\ Teacher Education of Early Childhood Education FKIP Universitas Riau, \\ Pekanbaru, Indonesia
}

\begin{abstract}
The golden age is a critical period where parents must provide discipline as an initial foundation for children to be able to apply discipline early on. Cultivation of discipline needs to start as early as possible starting from within the family, the educational environment, and the community environment. This article will use the literature review method sourced from books and scientific journals in explaining the definition of discipline, the importance of discipline, and the discipline of learning strategies that can be carried out in early childhood. The purpose of writing this article is to give readers an understanding of the importance of discipline and strategies that can be done by parents and teachers in teaching discipline to young children. The things that can be done by parents and teachers is by practising the discipline of children routinely and consistently, getting used to behaving by values based on moral standards, and the need for parental control to develop internalized children. Besides, also recognize the age and stage of child development, invite children to talk from heart to heart, apply the consequences they receive when doing an action and finally give praise to the child when it is disciplined.
\end{abstract}

Keywords: discipline, children, educating

\section{ABSTRAK}

Masa keemasan merupakan masa kritis bagi orangtua untuk memberikan penanaman kedisiplinan awal bagi anak agar dapat menerapkan disiplin sejak dini, karena akan menentukan kedisiplinan anak pada tahap perkembangan selanjutnya. Penanaman disiplin perlu dimulai sedini mungkin mulai dari dalam lingkungan keluarga, lingkungan pendidikan, dan lingkungan masyarakat. Melalui disiplin anak dapat belajar berperilaku sesuai dengan cara yang disetujui oleh lingkungan sosial. Artikel ini akan menggunakan metode kajian literatur yang bersumber dari buku dan jurnal ilmiah dalam menjelaskan definisi disiplin, pentingnya disiplin, dan strategi pembelajaran disiplin yang dapat dilakukan pada anak usia dini. Tujuan penulisan artikel ini untuk memberikan pemahaman pada pembaca mengenai pentingnya disiplin dan strategi yang dapat dilakukan oleh orang tua dan guru dalam mengajarkan disiplin pada anak usia dini. Hal-hal yang dapat dilakukan oleh orang tua dan guru adalah dengan cara melatih disiplin anak secara rutin dan konsisten, membiasakan diri berperilaku sesuai dengan nilai-nilai berdasarkan acuan moral, dan perlu adanya kontrol orang tua untuk mengembangkannya terinternalisasi dalam diri anak. Selain itu juga kenali usia dan tahap perkembangan anak, ajak anak berbicara dari hati ke hati, terapkan konsekuensi yang mereka terima bila melakukan suatu tindakan dan terakhir beri pujian pada anak apabila sudah disiplin.

Kata Kunci: disiplin, anak, mendidik

\begin{tabular}{|c|c|c|}
\hline Submitted & Accepted & Published \\
\hline 30 Agustus 2019 & 04 November 2019 & 13 November 2019 \\
\hline
\end{tabular}

\begin{tabular}{|l|c|c|c|}
\hline Citation & $:$ & $\begin{array}{c}\text { Chairilsyah, D. (2019). Educating Children To Be A Discipline Person. Jurnal PAJAR (Pendidikan dan Pengajaran), } \\
3(6), 1282-1288 . \mathrm{DOI}: \text { http } / / \text { dx doi org } / 10.33578 / \text { pir.v3i6.7880. }\end{array}$ \\
\hline
\end{tabular}

\section{INTRODUCTION}

The age of pre-school children is important in the stages of a child's life. At this stage, it is also called the golden age for a child. This stage has a very important and valuable meaning because this period is the initial foundation for the child's future. Besides, children have the freedom to explore certainly according to the rules in their environment. Therefore, at this age, parents must provide inculcation of discipline as an initial foundation for children to be able to apply discipline early on. The formation of this initial discipline will influence and also determine the discipline of children at a later stage of development.

The foundation of discipline from an early age is important for the development of children's behaviour because this period is a very effective time for the formation of early moral behaviour of children. Every child has the potential to understand the rules that apply in his environment and will continue to develop at 
every stage of his life. Discipline is needed to help the child's personal and social adjustment. Koesoema (2010) explains that through discipline children can learn to behave in ways that are approved by the social environment.

Discipline is the way society teaches children about moral behaviour that is accepted by groups. But most people consider discipline as something rigid so that it seems to force children to follow the rules that have been set immediately. They do not realize that discipline is a learning process that continues all the time. Thus, it can be said that discipline is a very important influence in the process of forming children's behaviour to become a person who can behave by the rules that apply in society. Discipline needs to be instilled from an early age because it will affect the moral development of children in the future. To avoid mistakes of the application of discipline, it is necessary to have a proper discipline of character education. This can be started from instilling discipline which is carried out starting from home that is by parents and strengthened by instilling discipline by teachers in schools so that child can behave discipline precisely and consistently.

Muslich (2011) explains that skills that are important in the success of children in school and life begin with the basic ability of children to learn to be disciplined. According to Sudarna (2014) instilling discipline needs to start early. Discipline is not a restraint on children and also not giving absolute freedom to children. Discipline directs children to learn about good things for their future. the goal is that they can live happily, successfully, and lovingly. When parents or teachers overly curb and use punishment in disciplining children, then it will greatly affect the child's personality in the future so that children will grow into individuals who are rigid, timid, do not dare to express themselves, become angry and aggressive individuals. Conversely giving excessive freedom will lead children to be impulsive, breaking the rules and engaging in promiscuity as a teenager.

Child discipline cannot be achieved without an educational process. The process begins with the inculcation of the values of disciplinary behaviour carried out by adults in children. By providing inculcation of disciplinary values, children will get a full knowledge of a discipline. When children have gained knowledge about discipline as a whole then the child will realize that discipline is important for his life, eventually the child will voluntarily perform disciplined behaviour without the need to be reminded by parents or teachers (Sudaryanti, 2012).

Cultivation of discipline needs to start as early as possible starting from within the family, the educational environment, and the community environment. Fathurrohman et al (2013) explains that parents and teachers play an important role in instilling discipline in children because parents and teachers are the initial and closest environment to the child. The discipline rules that are applied to children must form an agreement between home and school. Sudarna (2014) explains that three basic characteristics must be possessed by every individual, namely unselfish, honest, and disciplined. All three must be present and not negotiable because it is a basic principle for forming good behaviour for children. According to him, if one is not fulfilled then the individual fails to become an individual with a positive character. If an individual has a selfish nature, then he will be a destroyer in a group, dishonest individuals will destroy trust, and undisciplined individuals will result in a series of delays that damage the system in their environment. At this time the three basic characters, especially the character of discipline is increasingly eroded.

The purpose of writing this article is to provide understanding to parents and teachers about the definition of discipline in early childhood. This article will also provide an understanding of the importance of disciplinary behavior for early childhood. In addition, through this article will explain how concrete strategies that can be done by parents at home and teachers at school to teach disciplinary behavior to children from an early age. 


\section{LITERATURE REVIEW}

According to James Drever, discipline is the ability to control behaviour that comes from within a person by things that have been regulated from the outside or existing norms. Theistic mental discipline learning theory comes from power psychology or psychology faculty. According to this theory, the individual or child chooses some mental powers such as thoughts, memories, attention, abilities, decisions, observations, responses, and so on. Each of these power can be improved through exercises. Thus, learning aims to train these powers (Suwartini, 2018).

Theory of learning Humanistic mental disciplines originates from the flow of classical Humanistic Psychology created by Plato and Aristotle. This theory is the same as the theological mental discipline, that is, when those powers are trained, they will get stronger, and when they are already strong, the individual concerned can easily solve various problems encountered. The difference is in the training process. If the theistic mental theory trains part by part of a child's power or potential, then the humanistic mental discipline emphasizes the whole as an individual's full potential (Pidarta, 2013).

According to Pratt Fairchild in terms of sociology, discipline consists of two parts, namely discipline from within and also social discipline. Both are related to one another so that someone who has a disciplined attitude is people who can direct their behaviour and actions based on certain standards or limits of behaviour that are accepted in each group or social environment. According to John Macquarrie in terms of ethics, discipline is a willingness and deed of someone in complying with all the rules that have been coupled with specific goals (Wibowo, 2012).

Discipline is an attitude that is always the right promise so that others trust it. Discipline comes from the Latin 'Discere' which means

\section{MATERIAL AND METHODS}

A literature study is one technique that can be used in carrying out research. A literature study is a way to solve problems by tracing the learning or 'Disciplina' which means teaching or training. Discipline comes from English, 'Disciple' which means follower or student. At this moment, the word 'discipline' experiences development of meaning in several senses. First, discipline is defined as compliance with regulations or subject to supervision and control. Second, disciplines are exercises that aim to develop themselves to behave in an orderly manner. The word discipline means training and obedience to the rules. It means that all parties can guarantee the survival and smoothness of learning, working and trying (Umari et al, 2018).

The essence of general education is the process of presenting situations and conditions that enable as many students as possible to expand and deepen the essential meanings to achieve a human life. Therefore, it is very necessary to have intentionally or awareness to invite him to act by the objectives. Thus, the essence of general education, includes two dimensions, namely the pedagogic dimension and the substantive dimension. The dimension of pedagogic is the process of presenting situations and conditions that as many students as possible are invited to expand and deepen the substantive dimension (Muslich, 2011).

General education is carried out in a family, school and community environment. Thus, the family is one of the institutions that develop the duties and responsibilities in achieving general education goals. The essential goal of general education is to strive for students to become whole and integrated individuals. To achieve this goal, the task and responsibility of the family (parents) are to create situations and conditions that contain a climate that can be lived by children to deepen and expand essential meanings. Parents can implement it by creating situations and conditions that are lived by children so that they have the basics in developing discipline.

sources of writings that have been made before. In the research to be carried out, of course, a researcher must have a broad insight related to the 
object to be studied. If not, it can be ensured that the research will fail (Sugiyono, 2015).

Resources that can be used as material for literature studies should not be arbitrary since not all research papers can be used as a reference. Some of the most common and feasible uses are books by trusted authors, accredited scientific journals, and student research results in various forms such as theses, dissertations, practicum reports, and so on. Several methods can be carried out to conduct literature studies, such as criticizing, comparing, summarizing, and gathering (synthesizing) literature (Sugiyono, 2015).

To understand in-depth related to the object of research, this literature study technique can be used as one of the best ways. The

\section{RESULTS AND DISCUSSION}

Disciplined children have self-order based on cultural values, social rules, outlook on life, and attitudes that are meaningful to themselves, the people of the nation and the State. This means that the responsibility of parents is to strive for children's self-discipline to carry out relationships with themselves and the natural environment and other living things based on moral values. Chairilsyah (2016) said that the goal of self-discipline is to work on developing children's interests and developing children to become good human beings, good friends, good neighbours and citizens.

Furthermore, an indication that democratic parenting practices provide dialogical communication between children and parents and the existence of warmth that makes children feel accepted by parents. Therefore, children who feel accepted by parents allow them to understand and internalize messages of moral values. The family can be viewed from the dimensions of blood relations and social relations. The family in the dimension of blood relations is a social unit that is bound by a blood relationship between one another (Istiqomah, 2004).

In various dimensions and understanding of the family, the essence of the family (mother and father) is wholeness is seeking children to researcher will not only know things about the object of research but also can make conclusions from the results of the writings of previous researchers. Thus, the researcher can make updates in the research and the final result may be varied.

This research uses primary and secondary sources on the topic of the nature and behavioural problems of discipline in early childhood. The researcher seeks to provide an understanding of the importance of this disciplinary behaviour which can positively influence early childhood development. Besides, the researcher also tries to provide opinions and suggestions for teachers and parents in educating children who are not yet disciplined to become disciplined individuals both at school and at home.

have and develop a disciplined attitude. The integrity of parents (father and mother) in a family is needed in helping children to have and develop a disciplined attitude. A whole family provides a great opportunity for children to build trust in their parents, which is an essential element in helping children have and develop discipline. The trust of the parents felt by the child will result in the direction, guidance and assistance of the parents given to the child to unite and make it easier for the child to grasp the meaning of the efforts made (Silahudin, 2017).

If community and school are the joints of human guidance, the household is the main influencer which is stronger than the influence at school or in the community. As leaders, parents must be able to guide, direct, supervise and move the child to be full of passion to motivate children. Parents should be able to communicate so that mutual trust emerges with the child. Parents know exactly about their children, from experiences from infancy to childhood our children already know the advantages and disadvantages, so flexibility is needed to change behaviour to want to excel. Parents must constantly pay attention to the child's development. Families can create a comfortable atmosphere at home so that children feel at home near their role models. Create a sense of security 
in him, lest our children feel safer in the environment of their friends than in the family environment. Discipline arising from within a child is the result of direction and guidance from parents of discipline products (Marliany, 2014).

Discipline requires a learning process, at the beginning of the learning process there need to be the efforts of parents (Suwartini, 2018). The things that parents can do are:

1. Train the child's discipline routinely and consistently.

2. Familiarize yourself behaving by values based on moral references, this aims so that children are trained and accustomed to behaving by moral values.

3. Parental control is needed to develop its internalized.

In this context, parents' efforts to foster children's self-control based on religious moral values should be as interpreted in other moral values (social, economic, scientific/learning, democracy, and order) values. In other words, moral values are a reflection of religious values because they provide clear direction for children and reflect discipline. These three efforts are called external controls. This democratic control and openness make it easy for children to internalize moral values. This external control can create a world of togetherness which is an essential condition for shared appreciation between parents and children (Rustini, 2012). Thus self-discipline is a behaviour that can be accounted for because it is controlled by moral values. Thus, it can be concluded that when every parent in helping a child to have selfcontrol, means that they have been able to: help children to have self-management, intervene in children, give positive values to children and provide appropriate punishment.

Tips and techniques for applying discipline to children that can be done by parents and teachers, including:

1. Make mutual respect between parent/teacher and child.

2. Have a sense of empathy for the situation and condition of the child.

3. Know the age and stage of development of children in the application of the discipline.
4. Encourage the child to talk from heart to heart in providing habituation and understanding of the discipline.

5. Be consistent in carrying out discipline programs that have been planned.

6. Anticipating and preventing side effects from the discipline program that is being carried out.

7. Give choices, but still give them limits in daily activities, do not be too tense and rigid in educating children.

8. Apply the consequences they receive when doing something wrong.

9. Give praise to the child if the child succeeds or achieves better development in carrying out the discipline program.

Thus, every effort made in helping a child is preceded by the appearance of:

1. Exemplary behaviour. It means that each behaviour is not just a behaviour that is mechanical but must be based on the awareness that this behaviour will be used as a place of imitation and identification for children. Therefore, the actualization must always be aimed at the observance of moral values, especially when meeting with children.

2. Self-awareness. This behaviour must also be transmitted to the children by encouraging them so that their daily behaviour is obedient to moral values. Therefore, parents always help them to be able to make selfobservation through dialogic communication both verbally and nonverbally because this will bridge the gaps which often triggers children behaving aggressively or not disciplined.

3. Dialogical communication that occurs between parents and their children, especially those related to efforts to help them to solve problems regarding moral values. This means they have been able to intervene peacefully against mistakes or deviations of behaviour and have made efforts to improve it. In other words, parents have been able to exercise control over their children's behaviour so that they continue to have and enhance moral values as the basis 
for disciplined behaviour. Through this control, deviant behaviour can be corrected.

4. Subsequent efforts to foster children's obedience to moral values can be actualized in managing the physical environment called the physical moment. This can support the creation of a climate that invites children to dialogue with moral values in the packaging, for example, the existence of wall hangings, magazines, cabinets or bookshelves containing religious books, clean and orderly rooms, and items neatly arranged. Besides, the choice of place of residence can activate children with moral values.

5. Structuring the physical environment that involves the world will make the child stronger in ownership of moral values and more invited to improve it. This happens if parents can work for children to get closer and closer to moral values. Efforts can be actualized by managing the social environment because in its arrangement moral values can be packaged in patterns of relationships between families, ways of communication, cohesiveness and the existence of educational indications. This

\section{CONCLUSIONS AND RECOMMENDATIONS}

Discipline is an attitude that is always the right promise so that others trust it in their daily lives. The family is the deciding factor in forming the nature and habit patterns of the discipline so that it can be implemented in the family, school and community environment. Thus, the family is one of the institutions that develop the duties and responsibilities in achieving general education goals. Besides, the role of teachers in schools from an early age also helps parents in the formation of the nature and behaviour of the child's discipline through learning activities, learning methods, instructional materials and learning media that are planned and systematic to improve disciplinary behaviour in early arrangement is the realization of parents in taking responsibility for their role, namely providing assistance to foster self-control of their children. Related to this, parents are required to create a pattern of communication between family members with moral values. This communication pattern can do through movement, caress, smile, or expression. This communication pattern can make family members more intimate, have each other, and feel secure in the family.

6. Structuring the social environment can present a situation of togetherness between children and parents. The situation of togetherness is the main condition for the creation of appreciation and meeting between parents and children.

Structuring the educational environment will be more meaningful if it can present a climate that encourages its mentality to learn moral values. Efforts that can be done by parents are managing the psychological atmosphere in the family. Structuring the psychological atmosphere in the family touches the best dimension for fostering children to develop their character and character.

childhood.

Some suggestions for development to improve the development of children's disciplinary behaviour include: 1) Create a sense of security in children, lest our children feel safer in the environment of their friends than in the family environment. 2) The process of forming discipline in children, namely training, independently behaving in accordance with values based on moral standards, if the child has been trained and accustomed to behaving in accordance with moral values, 3) There needs to be parental control to develop disciplinary behaviour in order to be internalized with both at home and school. 


\section{REFERENCES}

Chairilsyah, D. (2016). Metode dan Teknik Mengajarkan Kejujuran Pada Anak Sejak Usia Dini. Jurnal Educhild. 5(1), 8-14.

Fathurrohman, P., Suryana, AA \& Fatriany, F. (2013). Pengembangan Pendidikan Karakter. Bandung: PT. Refika Aditama.

Istiqomah, U. (2004). Merawat dan Mendidik Anak. Surakarta: PT. Widya Duta Grafika.

Koesoema, D. (2010). Pendidikan Karakter. Jakarta: Grasindo.

Marliany, R. (2014). Psikologi Umum. Bandung: Pustaka Setia.

Muslich, M. (2011). Pendidikan Karakter: Menjawab Tantangan Krisis Multidimensional. Jakarta: Bumi Aksara.

Pidarta, M. (2013). Landasan Pendidikan. Jakarta: Rineka Cipta.

Rustini. (2012). Pendidikan Karakter Anak Usia Dini. Jurnal Cakrawala Dini. 3(1). DOI 10.17509/cd.v3i1.10321
Silahudin. (2017). Urgensi Membangun Karakter Anak Sejak Usia Dini. Jurnal UIN ArRaniry. 3(2), 18-41.

Sudarna. (2014). Pendidikan Anak Usia Dini Berkarakter. Yogyakarta: Genius Publisher.

Sudaryanti. (2012). Pentingnya Pendidikan Karakter Bagi Anak Usia Dini. Jurnal Pendidikan Anak. 1(1), DOI 10.21831/jpa.v1i1.2902.

Sugiyono. (2015). Metode Penelitian Kuantitatif, Kualitatif dan $R \& D$. Bandung: Alfabeta.

Suwartini, S. (2018). Pengembangan Buku Ajar Pendidikan Karakter dengan Pendekatan Pembelajaran Berbasis Soft Skill Pada Siswa SD Kelas II. Jurnal Educhild. 7(2), 102-106.

Umari, T \& Rosmawati. (2018). Analisis Nilainilai Karakter Cerdas Mahasiswa FKIP Universitas Riau. Jurnal Educhild. 7(2), 118-126.

Wibowo, A. (2012). Pendidikan Karakter Usia Dini. Yogyakarta: Pustaka Pelajar. 